\title{
Prevalence of polycyclic aromatic hydrocarbons (PAHs) degrading bacteria in contaminated tropical soil in Lagos, Nigeria: involvement of plasmid in degradation
}

\author{
M.N. IGWO-EZIKPE ${ }^{1 *}$, J. OKPUZOR $^{2}$, O. AWODELE ${ }^{3}$, F.O. NWAOKORIE ${ }^{4}$, \\ M.A. FOWORA ${ }^{4}$ and M.O. AKINBO ${ }^{1}$ \\ ${ }^{1}$ Department of Biochemistry, College of Medicine, University of Lagos, Lagos, Nigeria \\ ${ }^{2}$ Department of Cell Biology and Genetics, University of Lagos, Lagos, Nigeria \\ ${ }^{3}$ Department of Pharmacology, College of Medicine, University of Lagos, Lagos, Nigeria \\ ${ }^{4}$ Molecular Biology and Biotechnology Division, Nigerian Institute for Medical Research, Yaba, Nigeria. \\ Corresponding author, E-mail: mimiigwo@yahoo.co.uk
}

\begin{abstract}
Recalcitrant pollutants such as polycyclic aromatic hydrocarbons (PAHs) are difficult to degrade and have been the focus for biodegradation. They form a class of pollutant on a global scale. In an attempt to contribute to the search for suitable microbial culture with potential to biodegrade low and high molecular weight PAHs, bacterial strains were isolated from engine-oil polluted sites in Lagos, Nigeria. These isolates were evaluated for possession of plasmid DNA and the role it played in PAH degradation. Out of sixteen strains isolated, two were Gram negative while the others were Gram positive isolates. They belonged to genera Micrococcus, Staphylococcus, Kurthia sp., Acinetobacter, Pseudomonas and Corynebacterium. All the isolates grew on the PAHs (anthracene, fluoranthene and pyrene) at varying rates utilizing them as sole source of carbon and energy. All the isolates also possessed plasmid DNA ranging from 17.8 to $38.9 \mathrm{kbp}$. Subjection of plasmid cured isolates to PAHs biodegradation suggest that PAHs degradation may be plasmid and/or chromosomally mediated depending on the bacterial isolate and PAHs being degraded. This study has revealed that different compounds induce varied genetic changes in bacterial isolates in response to the stimuli.

(c) 2010 International Formulae Group. All rights reserved.
\end{abstract}

Keywords: Biodegradation, Bacteria, Plasmid, Polycyclic aromatic hydrocarbons.

\section{INTRODUCTION}

Polycyclic aromatic hydrocarbons (PAHs) are a class of fused-ring aromatic compounds known as ubiquitous environmental pollutants (Ockenden et al., 2003; Tao et al., 2006). PAHs are components of crude oil, wood preservatives, smoke houses and also found in emissions from power generators and motor vehicles
(Christensen et al., 2005; Wilcke, 2007). They can travel long distances in the atmosphere thus, they are globally distributed. The concentration of $\mathrm{PAH}$ in the environment varies widely, depending on the level of industrial development, proximity of the contaminated sites to the production source and the mode of PAH transport (Mrozik et al., 2003). PAHs are commonly found in air, soil, 
estuarine water and sediments as pollutants (Ogunfowokan et al., 2003; Masih and Taneja, 2006; Cai et al., 2007; Tian et al., 2008). Some of these PAHs are known for their recalcitrance, persistence and bioaccumulation properties. They can be highly toxic, mutagenic and/or carcinogenic especially those with high molecular weight like chrysene, pyrene and fluoranthene (Xue and Warshawsky, 2005). They therefore pose serious health concern on aquatic and terrestrial life (Weinstein et al., 2003; Meudec et al., 2006; Reynaud and Deschaux, 2006; Castorena-Torres et al., 2008).

Microbial biotransformation has been shown to be the principal process for the elimination of PAHs from the environment. The use of microorganisms for bioremediation of PAHs contaminated sites is considered as an efficient and cost effective technology for restoration of polluted sites (Samanta et al., 2002; Rehmann et al., 2008). The role of microbes in utilization of PAHs in the environment is in one part, the normal process of carbon cycle, and on the other, a method of removing man made pollutants from the environment.

In order to study the fate of PAHs in the environment, considerable efforts have been focused on the isolation of microorganisms able to degrade them. Studies have shown the degradation of both low molecular weights and few high molecular PAHs (Santos et al., 2008; Igwo-Ezikpe et al., 2010). However, understanding the location of the PAHs degradation gene(s) on the microbes is of paramount importance in practical application. Genetic exchange by horizontal gene transfer contributes to acquiring new catabolic pathways in microbial communities present in diverse environments (Springael and Top, 2004). Moreover, a potential candidate for bioremediation studies should be able to survive in the environment, retain its degradation potential and/or transfer its degradation gene to surrounding organisms.
Therefore, the aims of this study include (1) isolate and partially characterize PAHs degrading bacteria from engine oil impacted soil, (2) evaluate the possession of plasmid DNA by the isolates and (3) investigate the role of plasmid DNA in PAHs degradation.

\section{MATERIALS AND METHODS \\ Chemicals and media}

All the reagents; polycyclic aromatic hydrocarbons (pyrene, fluoranthene and anthracene) and ethanol were sourced from Sigma chemical Co. (Germany). The media (Nutrient agar, Mueller Hinton agar, Mannitol salt agar, Maconkey agar, Bacteriological agar were obtained From Oxoid, UK, while the molecular reagents; Agarose, Bromophenol blue, Ethidium bromide and Hind III digest of Lambda DNA were from Promega, USA. All PAHs had purity $\geq 96 \%$.

\section{Isolation and identification of microorganisms}

Soil samples were collected from five different engine oil polluted mechanic workshop sites located at Surulere area of the Lagos metropolis in Western part of Nigeria. Samples were collected using sterilized spatula at a tillage depth of $2 \mathrm{~cm}$ randomly from 20 core points. The soil samples were mixed and a sub-soil collected into a sterile universal container and transferred to the laboratory at $4{ }^{\circ} \mathrm{C}$ within $2 \mathrm{hr}$. A 10 -fold serially diluted sub-soil sample was inoculated onto Mannitol salt agar plates sterilized by autoclaving at $121{ }^{\circ} \mathrm{C}$ for $20 \mathrm{~min}$. Plates were incubated at $37{ }^{\circ} \mathrm{C}$ for $18-24 \mathrm{hr}$. Discrete colonies were further purified by subculturing on sterilized Mueller Hinton agar and MacConkey agar respectively and incubated at $37{ }^{\circ} \mathrm{C}$ for 18-24 hr. Morphological and biochemical studies such as Gram's reaction, slide agglutination, tube coagulase, catalase, citrate utilization, oxidase and sugar fermentation were performed as 
described by Barrow and Felthanm (2003). Further identification of the isolates was also carried out according to the method of Holt et al. (1994).

\section{Growth of isolates on polycyclic aromatic hydrocarbons}

Isolates were cultured on sterilized solid mineral salt media (MSM) agar plates containing anthracene, fluoranthene and pyrene respectively as the sole carbon and energy source by spray-plate technique (IgwoEzikpe et al., 2010). MSM composed per liter (pH 7.2): $\mathrm{NH}_{4} \mathrm{NO}_{3}, 4.0 \mathrm{~g} ; \mathrm{Na}_{2} \mathrm{HPO}_{4}, 2.0 \mathrm{~g}$; $\mathrm{KH}_{2} \mathrm{PO}_{4}, 0.53 \mathrm{~g} ; \mathrm{K}_{2} \mathrm{SO}_{4}, 0.17 \mathrm{~g}, \mathrm{MgSO}_{4} .7 \mathrm{H}_{2} \mathrm{O}$, $0.10 \mathrm{~g}$ and trace elements solution $(1 \mathrm{ml})$, sterilized by autoclaving at $121{ }^{\circ} \mathrm{C}$ for $20 \mathrm{~min}$. Culture plates were wrapped with aluminum foil and black polyethylene bag, and incubated in the dark at $30 \pm 2.0{ }^{\circ} \mathrm{C}$ for 14 days. Control plates (devoid of PAHs) were also incubated. Bacterial colonies that formed clear zones on the PAH coated plates indicated positive growth, these were compared to control nonPAH MSM agar plates and scored.

\section{Evaluation of plasmid DNA possession and involvement in PAHs degradation}

In order to evaluate the role played by plasmid DNA in PAHs degradation, the isolates were evaluated for possession of plasmid. Thereafter, their plasmids were cured and isolates reevaluated for PAHs degradation.

\section{Plasmid DNA extraction and agarose electrophoresis}

An overnight culture of bacterial cells on Mueller Hinton agar were used for plasmid DNA extraction using TENS method (Zhou et al., 1990). Bacterial cells were emulsified in $200 \mu \mathrm{l}$ of normal saline in $1.5 \mathrm{ml}$ eppendorf tubes and $300 \mu \mathrm{l}$ of TENS solution added. On mixing for 3-5 min, $150 \mu \mathrm{l}$ of $3 \mathrm{M}$ sodium acetate was then added, vortex for $10 \mathrm{sec}$, centrifuged at $14000 \times g$ for $15 \mathrm{~min}$ and the supernatant transferred into another eppendorf tube. Absolute ethanol $(900 \mu \mathrm{l})$ was added to the supernatant to precipitate the DNA, thereafter pellet was rinsed with ethanol (70\%; $0.1 \mathrm{ml}$ ) and then suspended in $40 \mu \mathrm{L}$ of Tris EDTA buffer (TE Buffer). DNA solutions were subjected to $0.8 \%$ agarose electrophoresis with Tris borate buffer (TBE buffer) containing two drops of ethidium bromide $(0.5 \mathrm{mg} / \mathrm{ml})$. The samples and DNA molecular marker (Hind III digest of Lambda DNA) were mixed with bromophenol blue and then loaded onto gel wells. Electrophoresis was carried out at $60 \mathrm{~V}$ (Thermo EC machine, CBS Scientific, USA) for $1 \mathrm{hr} 30 \mathrm{~min}$. The gel was then removed from the tank and placed on a UVtransilluminator and photographed with polaroid film.

Plasmid DNA curing, extraction and agarose electrophoresis

Overnight culture of isolates on Mueller Hinton agar were inoculated respectively into $5 \mathrm{ml}$ sterilized acridine solution $(0.1 \mathrm{mg} / \mathrm{ml}$ acridine orange in nutrient broth) and incubated at $37{ }^{\circ} \mathrm{C}$ for 18 $24 \mathrm{hr}$. Thereafter, the organisms were plated out on Nutrient agar and were subsequently subjected to plasmid extraction and agarose electrophoresis as previously described (Zhou et al., 1990).

\section{Growth of cured isolates on polycyclic aromatic hydrocarbons}

Overnight cultures of cured isolates were harvested from Mueller Hinton agar onto freshly prepared sterilized MSM agar containing anthracene, fluoranthene and pyrene respectively as the sole carbon and energy source by spray-plate technique (IgwoEzikpe et al., 2010). Culture plates were wrapped with aluminum foil and black polyethylene bag, and incubated in the dark at $30 \pm 2.0^{\circ} \mathrm{C}$ for 14 days. Control plates (devoid of PAHs) were also included. Cleared zones on MSM PAH plates were scored. 


\section{RESULTS}

Isolation and identification of microorganisms

Sixteen bacterial isolates were obtained from soils within the sites of mechanic workshops. Morphological and biochemical studies showed two of the isolates to be Gram negative; these were Acinetobacter calcoaceticus and Pseudomonas stutzeri while the Gram positive isolates included Micrococcus kristinae, Staphylococcus epidermis, Staphylococcus agilis, Kurthia sp., Staphylococcus hyicus, Staphylococcus saccharolyticus, Staphylococcus aureus, Staphylococcus schleiferi, Micrococcus sedentarius, Staphylococcus intermedius, Staphylococcus schleiferi, Micrococcus lylae, Staphylococcus intermedius and Corynebacterium ammoniagenes (Table 1).

\section{Growth of bacterial isolates on PAHs}

The bacterial isolates were observed to grow on anthracene, fluoranthene and pyrene to different extent (Table 2). Kurthia sp., Staphylococcus aureus, Micrococcus lylae and Pseudomonas stutzeri showed highest growth on the three PAHs used compared to the other isolates. Isolates with the least growth on anthracene were Staphylococcus epidermis and Staphylococcus schleiferi while Staphylococcus intermedius had the least growth on fluoranthene. Isolates with the least growth on pyrene were Staphylococcus agilis and Staphylococcus intermedius.

\section{Plasmid DNA evaluation and curing}

This investigation showed that all the bacterial isolates had plasmids with molecular weights range of 17.8 - $38.9 \mathrm{kbp}$ (Plates 1). Two of these isolates; Staphylococcus intermedius and Micrococcus lylae had multiple plasmids of 21.7, $32.7 \mathrm{kbp}$ (Table 3). None of the sixteen bacterial isolates showed presence of plasmid after curing with acridine orange.

\section{Growth of bacterial isolates on PAHs after acridine orange treatment}

Treatment with acridine orange resulted in S. schleiferi and S. intermedius not being able to utilize anthracene, fluoranthene and pyrene as sole source of carbon and energy for growth (Table 4). Moreover, the acridine orange treated bacterial isolates showed some degree of altered growth on the PAHs depending on the PAH used. These isolates include Micrococcus kristinae, S. epidermis, $S$. agilis, Acinetobacter calcoaceticus, $S$. hyicus, S. aureus, S. schleiferi, Micrococcus sedentarius, S. intermedius, Micrococcus lylae, Pseudomonas stutzeri and Corynebacterium ammoniagenes. However, there was no observable change in the growth of Kurthia sp., Staphylococcus saccharolytics on various PAHs after their treatment with acridine orange (Table 5).

\section{DISCUSSION}

Biodegradability potential exists among bacterial strains that inhabit PAHs polluted sites ( $\mathrm{Yu}$ et al., 2005; Igwo-Ezikpe et al., 2010). This study was able to isolate and characterize PAHs degrading bacteria from engine oil impacted soil in Lagos metropolis, Nigeria. Most of the bacteria isolated were Gram positive species belonging to the genera; Staphyloccccus, Micrococcus, Kurthia sp., Corynbacterium and Gram negative species of the genus Pseudomonas and Acinetobacter. This corroborates with previous findings regarding dominance of certain species of bacteria in oil-contaminated soils (Viñas et al., 2005).

The observation that all sixteen isolates could utilized both anthracene (low molecular weight $\mathrm{PAH}$ ) and fluoranthene and pyrene (high molecular weight PAHs) as sole carbon source for growth support previous findings (Haimou et al., 2004; Kim et al., 2005).

The possession of plasmids by the PAH degrading isolates may be an important characteristic for such organisms. In addition, the treatment of the isolates with acridine orange which was efficient in the complete curing of the plasmid DNA of the isolates is in agreement with a previous study (Kumar et al., 2010). 

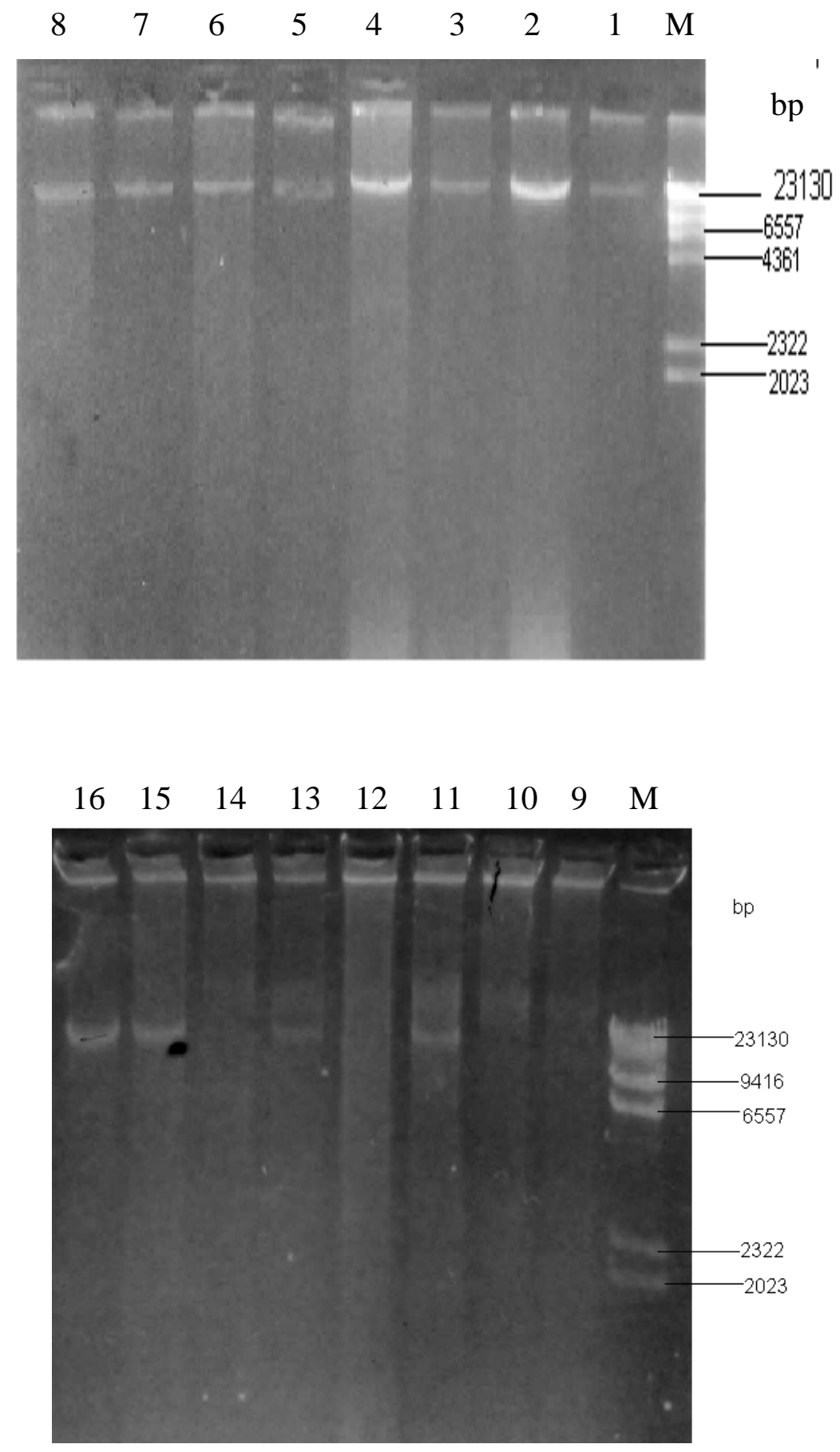

Plate 1: Agarose gel electrophoregram of plasmid DNA from PAH degrading bacterial isolates. Lane $1=$ Micrococcus kristinae. $2=$ Staphylococcus epidermis. $3=$ Staphylococcus agilis. $4=$ Kurthia sp. $5=$ Acinetobacter calcoaceticus. 6 = Staphylococcus hyicus. 7 = Staphylococcus saccharolyticus. $8=$ Staphylococcus aureus. $9=$ Staphylococcus schleiferi. $10=$ Micrococcus sedentarius. $11=$ Staphylococcus intermedius. $12=$ Staphylococcus schleiferi . $13=$ Micrococcus lylae. $14=$ Staphylococcus intermedius. $15=$ Pseudomonas stutzeri. $16=$ Corynebacterium ammoniagenes. 
M.N. IGWO-EZIKPE et al. / Int. J. Biol. Chem. Sci. 4(6): 2133-2145, 2010

Table 1: Morphological and Biochemical properties of the PAHs degrading bacteria.

\begin{tabular}{|c|c|c|c|c|c|c|c|c|c|c|c|c|c|c|c|c|}
\hline \multicolumn{17}{|c|}{ Colony Morphology } \\
\hline & 1 & 2 & 3 & 4 & 5 & 6 & 7 & 8 & 9 & 10 & 11 & 12 & 13 & 14 & 15 & 16 \\
\hline Gram Reaction & + & + & + & + & - & + & + & + & + & + & + & + & + & + & - & + \\
\hline morphology & cocci & $\cos$ & ci cocci & $\mathrm{i}$ rods & cocci & cocci & cocci & $\operatorname{coc}$ & i cocci & $\operatorname{cocc}$ & $\operatorname{cocci}$ & occi c & occi c & cocci & rods & rods \\
\hline \multicolumn{17}{|c|}{ Biochemical Test } \\
\hline Catalase & + & + & + & + & + & + & + & + & + & + & + & + & + & + & + & + \\
\hline Oxidase & + & - & + & - & - & - & - & - & - & + & - & - & + & - & + & - \\
\hline Citrate & - & - & + & + & + & - & - & - & + & + & + & - & + & + & + & - \\
\hline Coagulase test & - & - & - & - & + & - & + & + & - & + & + & - & + & + & + & - \\
\hline Slide & & & & & & & & & & & & & & & & \\
\hline Agglutination & - & - & - & - & - & - & + & - & - & - & - & + & - & + & - & - \\
\hline Tube coagulase & + & + & + & - & + & - & + & + & + & + & + & + & + & + & + & - \\
\hline \multicolumn{17}{|c|}{ Acid production from: } \\
\hline Arabinose & + & + & - & - & - & - & - & - & - & - & - & - & - & - & - & - \\
\hline Maltose & + & + & + & - & - & - & - & + & - & - & - & - & - & - & - & - \\
\hline Mannitol & + & - & + & - & - & - & - & + & - & - & + & - & - & + & - & - \\
\hline Fructose & - & + & - & - & - & + & + & - & - & - & - & - & - & - & - & - \\
\hline Sucrose & + & - & - & - & - & - & - & + & - & - & - & - & - & - & - & - \\
\hline Xylose & - & - & - & - & - & - & - & - & - & - & - & - & - & - & - & - \\
\hline Cellobiose & - & - & - & - & - & - & - & - & - & - & - & - & - & - & - & - \\
\hline
\end{tabular}

$1=$ Micrococcus kristinae. 2 = Staphylococcus epidermis. 3 = Staphylococcus agilis.

$4=$ Kurthia sp. $5=$ Acinetobacter calcoaceticus. $6=$ Staphylococcus hyicus

$7=$ Staphylococcus saccharolyticus. $8=$ Staphylococcus aureus. $9=$ Staphylococcus schleiferi. $10=$ Micrococcus sedentarius. $11=$ Staphylococcus intermedius.

$12=$ Staphylococcus schleiferi. $13=$ Micrococcus lylae. $14=$ Staphylococcus intermedius. $15=$ Pseudomonas stutzeri. $16=$ Corynebacterium ammoniagenes. 
Table 2: Growth of bacterial isolates on PAHs.

\begin{tabular}{lccc}
\hline Organism & \multicolumn{3}{c}{ Polycyclic aromatic hydrocarbons } \\
\hline & Anthracene & Fluoranthene & Pyrene \\
\cline { 2 - 4 } Micrococcus kristinae & +++ & ++ & +++ \\
Staphylococcus epidermis & + & ++ & +++ \\
Staphylococcus agilis & ++ & ++ & + \\
Kurthia sp. & +++ & +++ & +++ \\
Acinetobacter calcoaceticus & +++ & ++ & ++ \\
Staphylococcus hyicus & ++ & ++ & ++ \\
Staphylococcus saccharolyticus & ++ & ++ & ++ \\
Staphylococcus aureus & +++ & +++ & +++ \\
Staphylococcus schleiferi & ++ & +++ & ++ \\
Micrococcus sedentarius & ++ & +++ & ++ \\
Staphylococcus intermedius & ++ & +++ & ++ \\
Staphylococcus schleiferi & + & +++ & +++ \\
Micrococcus lylae & +++ & +++ & +++ \\
Staphylococcus intermedius & +++ & + & + \\
Pseudomonas stutzeri & +++ & +++ & +++ \\
Corynebacterium ammoniagen & +++ & +++ & ++ \\
\hline
\end{tabular}

$+++=$ high growth,$++=$ moderate growth,$+=$ low growth 
M.N. IGWO-EZIKPE et al. / Int. J. Biol. Chem. Sci. 4(6): 2133-2145, 2010

Table 3: Molecular weight of plasmid DNA from PAH degrading bacteria.

\begin{tabular}{lc}
\hline Organism & Molecular weight of plasmid (kbp) \\
\hline & \\
Micrococcus kristinae & 21.7 \\
Staphylococcus epidermis & 21.7 \\
Staphylococcus agilis & 21.7 \\
Kurthia sp. & 21.7 \\
Acinetobacter calcoaceticus & 21.7 \\
Staphylococcus hyicus & 21.7 \\
Staphylococcus saccharolyticus & 21.7 \\
Staphylococcus aureus & 21.7 \\
Staphylococcus schleiferi & 32.7 \\
Micrococcus sedentarius & 32.7 \\
Staphylococcus intermedius & $21.7,32.7$ \\
Staphylococcus schleiferi & 21.7 \\
Micrococcus lylae & $21.7,32.7$ \\
Staphylococcus intermedius & 38.9 \\
Pseudomonas stutzeri & 17.8 \\
Corynebacterium ammoniagenes & 17.8 \\
\hline
\end{tabular}


Table 4: Growth of Acridine orange-treated bacterial isolates on PAHs.

\begin{tabular}{lccc} 
Organism & \multicolumn{3}{c}{ Polycyclic aromatic hydrocarbons } \\
\hline & Anthracene & Fluoranthene & Pyrene \\
\cline { 2 - 4 } Micrococcus kristinae & ++ & - & - \\
Staphylococcus epidermis & + & - & - \\
Staphylococcus agilis & - & ++ & - \\
Kurthia sp. & +++ & +++ & +++ \\
Acinetobacter calcoaceticus & ++ & +++ & ++ \\
Staphylococcus hyicus & + & + & ++ \\
Staphylococcus saccharolyticus & ++ & ++ & ++ \\
Staphylococcus aureus & +++ & +++ & ++ \\
Staphylococcus schleiferi & +++ & +++ & +++ \\
Micrococcus sedentarius & ++ & +++ & +++ \\
Staphylococcus intermedius & +++ & +++ & ++ \\
Staphylococcus schleiferi & - & - & + \\
Micrococcus lylae & ++ & +++ & + \\
Staphylococcus intermedius & - & - & ++ \\
Pseudomonas stutzeri & ++ & +++ & +++ \\
Corynebacterium ammoniagen & +++ & +++ &
\end{tabular}

$+++=$ high growth, $++=$ moderate growth, $+=$ low growth, $-=$ no growth 
M.N. IGWO-EZIKPE et al. / Int. J. Biol. Chem. Sci. 4(6): 2133-2145, 2010

Table 5: Comparison of growth of bacterial isolates on PAHs before and after acridine treatment.

\begin{tabular}{|c|c|c|c|c|c|c|}
\hline \multirow[t]{3}{*}{ Organism } & \multicolumn{6}{|c|}{ Polycyclic aromatic hydrocarbons } \\
\hline & \multicolumn{2}{|c|}{ Anthracene } & \multicolumn{2}{|c|}{ Fluoranthene } & \multicolumn{2}{|l|}{ Pyrene } \\
\hline & Original & Cured & Original & Cured & Original & Cured \\
\hline Micrococcus kristinae & +++ & ++ & ++ & - & +++ & - \\
\hline Staphylococcus epidermis & + & + & ++ & - & +++ & - \\
\hline Staphylococcus agilis & ++ & - & ++ & ++ & + & - \\
\hline Kurthia sp. & +++ & +++ & +++ & +++ & +++ & +++ \\
\hline Acinetobacter calcoaceticus & +++ & ++ & ++ & +++ & ++ & ++ \\
\hline Staphylococcus hyicus & ++ & + & ++ & + & ++ & ++ \\
\hline Staphylococcus saccharolyticus & $s+$ & ++ & ++ & ++ & ++ & ++ \\
\hline Staphylococcus aureus & +++ & +++ & +++ & +++ & +++ & ++ \\
\hline Staphylococcus schleiferi & ++ & +++ & +++ & +++ & ++ & +++ \\
\hline Micrococcus sedentarius & ++ & ++ & +++ & +++ & ++ & +++ \\
\hline Staphylococcus intermedius & ++ & +++ & +++ & +++ & ++ & +++ \\
\hline Staphylococcus schleiferi & + & - & +++ & - & +++ & - \\
\hline Micrococcus lylae & +++ & ++ & +++ & +++ & +++ & ++ \\
\hline Staphylococcus intermedius & +++ & - & + & - & + & - \\
\hline Pseudomonas stutzeri & +++ & ++ & +++ & +++ & +++ & ++ \\
\hline Corynebacterium ammoniagen & +++ & +++ & +++ & +++ & ++ & +++ \\
\hline
\end{tabular}

$+++=$ high growth, $++=$ moderate growth,$+=$ low growth, $-=$ no growth 
From our observation, the complete loss of plasmid DNA in S. schleiferi and $S$. intermedius and their inability to grow on anthracene, fluoranthene and pyrene indicates that gene(s) encoding for the catabolic enzymes responsible for the degradation of the specific PAH may be plasmid mediated. This is in conformity with other research findings that catabolic pathways which encode different PAHs degradation may be located on plasmids (Filonov et al., 2000; Coral and Karagöz, 2005). Moreover, Credan et al. (1994) suggested that the activities of catechol dioxygenase involved in catabolism of PAHs may be mediated by plasmids. A previous study suggested that Pseudomonas strains harboring plasmids metabolizing naphthalene contains silent genes of meta-pathway that may 'switch-on' when the strains are grown on methylated naphthalene and salicylate derivatives (Filonov et al., 2000). The presence of $\mathrm{PAH}$-degradation genes on mobile genetic elements may indicate the easy spreading of PAH-catabolic abilities among bacteria in polluted soils as a result of conjugative gene-transfer (Springael and Top, 2004). This was evident in the observed transfer $\mathrm{PAH}$ degradation genes in microbial cultures (Akhmetov et al., 2008; Heinaru et al., 2009).

Nevertheless, the finding that some isolates had their plasmid(s) cured yet they possessed varied PAH degradation potential is an indication that their $\mathrm{PAH}$ degradation gene(s) may be plasmid and/or chromosomally mediated. Furthermore, the bacterial isolates which possessed plasmid and after total curing of their plasmid showed no change in PAHs degradability suggested that their PAHs degradability could be chromosomally mediated as earlier reported (Lily et al., 2010). In addition, the observed altered growth on PAHs by acridine orange treated isolates indicated that the presence of chemicals may possibly induce the translocation or recombination of some gene(s) in the bacteria. This may have lead to the expression of varied proteins and/or enzymes involved in degradation thus the observed changes in the various PAHs degradation. Microorganisms are constantly mutating in the environment in response to chemical stimulus which reflects their metabolic response. Moreover, gene rearrangement and expression of specific proteins are among bacterial adaptation strategies. This diverse metabolic response gives an insight into the highly microbial mechanistic activity occurring in various polluted sites.

\section{Conclusion}

Efforts are directed at isolating various strains of bacteria from indigenous PAHs polluted sites with desirable degradation abilities. For microbial bioremediation to be successfully implemented as a PAH remediation technology, it is essential to understand factors which influence this process in the ecosystem. Such factor includes the involvement of plasmid in PAHs degradation. This is because genetic exchange by horizontal gene transfer contributes to acquiring new catabolic pathways in microbial communities present in diverse environments. This present study has revealed the abundance of bacteria in oil-contaminated soil. The bacterial isolates possessed plasmids but PAHs degradation may be partially plasmid and/or chromosomally mediated although this depends on the bacterial isolate used and the PAHs being degraded. Present findings also suggest that the presence of chemicals in the environment could induce diverse metabolic responses due to genetic changes. Future research would focus on locating catabolic genes on plasmid(s) and chromosomes of PAHs degrading bacteria of tropic origin.

\section{REFERENCES}

Akhmetov LI, Filonov AE, Puntus IF, Kosheleva IA, Nechaeva IA, Yonge DR, Petersen JN, Boronin AM. 2008. Horizontal transfer of catabolic plasmids in the process of naphthalene 
biodegradation in model soil systems. Mikrobiologiia, 77: 29-39.

Barrow IG, Felthanm KAR. 2003. Cowan and Steel's Manual for the Identification of Medical Bacteria. Cambridge University Press: Edinburgh.

Cai QY, Mo CH, Li YH, Zeng QY, Katsoyiannis A, Wu QT, Férard JF. 2007. Occurrence and assessment of polycyclic aromatic hydrocarbons in soils from vegetable fields of the Pearl River Delta, South China. Chemosphere, 68: 159-168.

Castorena-Torres F, de León BM, Cisneros B, Zapata-Pérez O, Salinas JE, Albores A. 2008. Changes in gene expression induced by polycyclic aromatic hydrocarbons in the human cell lines HepG2 and A549. Toxicol. In Vitro, 22: 411-421.

Christensen ER, Bzdusek PA. 2005. PAHs in sediments of the Black River and the Ashtabula River, Ohio: source apportionment by factor analysis. Water Res., 39: 511-524.

Coral G, Karagöz S. 2005. Isolation and characterization of phenanthrenedegrading bacteria from a petrochemical refinery soil. Ann of Microbiolog., 55: 255-259.

Credan P, Wasserfallen A, Rekik M, Timmis NK, Harayama S. 1994. Substrate specificity of catechol 2,3-dioxygenase encoded by TOL plasmid pWW0 of Pseudomonas putida and its relationship to cell growth. J. Bacteriol., 176: 60746081.

Filonov AE, Karpov AV, Kosheleva AI, Puntus FI, Balashova VN, Boronin MA. 2000. The efficiency of salicylate utilization by Pseudomonas putida strains catabolizing naphthalene via different biochemical pathways. Process Biochem., 35: 983-987.

Haimou Z, Aristeidis K, Anna IK. 2004. Isolation and characterization of novel bacteria degrading polycyclic aromatic hydrocarbons from polluted Greek soils. Appl. Microbiol. Biotechnol., 65: 124-31.
Heinaru E, Vedler E, Jutkina J, Aava M, Heinaru A. 2009. Conjugal transfer and mobilization capacity of the completely sequenced naphthalene plasmid pNAH20 from multiplasmid strain Pseudomonas fluorescens PC20. FEMS Microbiol. Ecol., 70: 563-574.

Holt JG, Krieg NR, Sneath PHA, Staley JT, Williams ST. 1994. Bergey's Manual of Determinative Bacteriology. Williams and Wilkins: Baltimore; 532-551.

Igwo-Ezikpe MN, Gbenle OG, Ilori MO, Okpuzor J, Osuntoki AA. 2010. Mixture of high molecular weight polycyclic aromatic hydrocarbons biodegradation by tropical bacteria and via co-metabolism with phenanthrene. Res. J. Environ. Sci., 4: 317-326.

Igwo-Ezikpe MN, Gbenle OG, Ilori MO, Okpuzor J, Osuntoki AA. 2010. High molecular weight polycyclic aromatic hydrocarbons biodegradation by bacteria isolated from contaminated soil in Nigeria. Res. J. Environ. Sci., 4: 127-137.

Kim JD, Shim SH, Lee CG. 2005. Degradation of phenanthrene by bacterial strains isolated from soil in oil refinery fields in Korea. J. Microbiol. Biotechnol., 15: $337-345$.

Kumar G, Singla R, Kumar R. 2010. Plasmid associated anthracene degradation by Pseudomonas sp. Isolated from Filling Station Site. Nature and Science, 8: 89-94.

Lily MK, Bahuguna A, Dangwal K, Veena G. 2010. Optimization of an inducible, chromosomally encoded benzo [a] pyrene (BaP) degradation pathway in Bacillus subtilis BMT4i (MTCC 9447). Ann. Microbiolog., 60: 51-58.

Masih A, Taneja A. 2006. Polycyclic aromatic hydrocarbons (PAHs) concentrations and related carcinogenic potencies in soil at a semi-arid region of India. Chemosphere, 65: 449-456.

Meudec A, Dussauze J, Deslandes E, Poupart N. 2006. Evidence for bioaccumulation of PAHs within internal shoot tissues by a halophytic plant artificially exposed to 
petroleum-polluted

sediments. Chemosphere, 65: 474-481.

Mrozik A, Piotrowska-Seget Z, Labuzek S. 2003. Bacterial degradation and Bioremediation of polycyclic aromatic hydrocarbons. Pol. J. Environ. Stud., 12: 15-25.

Ockenden WA, Breivik K, Meijer SN, Steinnes E, Sweetman AJ, Jones KC. 2003. The global re-cycling of persistent organic pollutants is strongly retarded by soils. Environ. Pollut., 121: 75-80.

Ogunfowokan OA, Asubiojo IO, Fatoki SO. 2003. Isolation and determination of polycyclic aromatic hydrocarbons in surface runoff and sediments. Water, Air \& Soil Pollut., 147: 245-261.

Rehmann L, Prpich GP, Daugulis AJ. 2008. Remediation of PAH contaminated soils: Application of a solid-liquid two-phase partitioning bioreactor. Chemosphere, 73: 798-804.

Reynaud S, Deschaux P. 2006. The effects of polycyclic aromatic hydrocarbons on the immune system of fish: A review. Aquat. Toxicol., 77: 229-238.

Samanta SK, Singh OV, Jain RK. 2002. Polycyclic aromatic hydrocarbons: environmental pollution and bioremediation. Trends Biotechnol., 20: 243-248.

Santos EC, Jacques JSR, Bento MF, Peralba RMC, Selbach PA, Sá LSE, Flávio AO, Camargo OAF. 2008. Anthracene biodegradation and surface activity by an iron-stimulated Pseudomonas sp. Bioresource Technol., 99: 2644-2649.

Springael D, Top EM. 2004. Horizontal gene transfer and microbial adaptation to xenobiotics: new types of mobile genetic elements and lessons from ecological studies. Trends Microbiol., 12: 53-58.

Stuart-Keil KG, Hohnstock AM, Drees KP, Herrick JB, Madsen EL. 1998. Plasmids responsible for horizontal transfer of naphthalene catabolism genes between bacteria at a coal tar-contaminated site are homologous to pDTG1 from Pseudomonas putida NCIB 9816-4. Appl. Environ. Microbiol., 64: 3633-3640.

Tao S, Li XR, Yang Y, Lu XX, Chen HT, Shen WR. 2006. Dispersion modeling of polycyclic aromatic hydrocarbons from various sources in Tianjin, China. Environ. Sci. Technol., 40: 4586-4591.

Tian Y, Liu HJ, Zheng TL, Kwon KK, Kim SJ, Yan CL. 2008. PAHs contamination and bacterial communities in mangrove surface sediments of the Jiulong River Estuary, China. Mar. Pollut. Bull., 57: 707-715.

Viñas M, Sabaté J, Espuny MJ, Solanas AM. 2005. Bacterial Community Dynamics and Polycyclic Aromatic Hydrocarbon Degradation during Bioremediation of Heavily Creosote-Contaminated Soil. Appl. Environ. Microbiol., 71: 70087018.

Weinstein JE, Sanger DM, Holland AF. 2003. Bioaccumulation and toxicity of fluoranthene in the estuarine oligochaete Monopylephorus rubroniveus. Ecotoxicol. Environ. Safety, 55: 278-286.

Wilcke W. 2007. Global patterns of polycyclic aromatic hydrocarbons (PAHs) in soil. Geoderma., 141: 157-166.

Xue W, Warshawsky D. 2005. Metabolic activation of polycyclic and heterocyclic aromatic hydrocarbons and DNA damage: A review. Toxicol. Appl. Pharmacol., 206: 73-93.

Yu SH, Ke L, Wong YS, Tam NFY. 2005. Degradation of polycyclic aromatic hydrocarbons by a bacterial consortium enriched from mangrove sediments. Environ. Int., 31: 149-154.

Zhou C, Yang Y, Yong AY. 1990. 'Miniprep' in ten minutes. Biotechniques, 8: 172-173. 